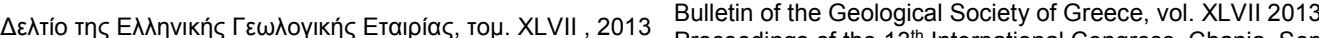
Proceedings of the $13^{\text {th }}$ International Congress, Chania, Sept.

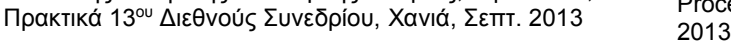

\title{
SOURCE ROCK POTENTIAL OF THE LATE MIOCENE METOCHIA FORMATION OF GAVDOS ISLAND, GREECE
}

\author{
Pyliotis I. ${ }^{1}$, Zelilidis A. ${ }^{2}$, Pasadakis N. ${ }^{3}$, Panagopoulos G. ${ }^{1}$ and Manoutsoglou \\ E. 1
}

${ }^{1}$ Technical University of Crete, Department of Mineral Resources Engineering, Research Unit of Geology, Chania, 73100, Greece

${ }^{2}$ University of Patras, Department of Geology, Laboratory of Sedimentology, Patra, 26110,

Greece

${ }^{3}$ Technical University of Crete, Department of Mineral Resources Engineering, Research Unit of Hydrocarbon Chemistry and Technology, Chania, 73100, Greece

\begin{abstract}
Rock-Eval method was used to analyze 53 samples from late Miocene Metochia Formation of Gavdos Island (south of Crete Island) in order to characterize the contained organic matter and to evaluate its potential as source rock. The samples were collected from Metochia Section which consists of about $100 \mathrm{~m}$ thick marlssapropels alternations. Organic matter analysis showed that the studied succession could be subdivided into two parts. The lower one, which is generally rich in organic matter and the upper one, which is poor. In the lower part the rich horizons in organic matter are characterized by Kerogen type II, III and IV, with low oxygen content, and with fair to very good potential for gas and/or oil hydrocarbon generation. Additionally, the studied samples are thermally immature. Taking into account that the studied area has never been buried in such a depth to reach conditions of maturation, as well as, that the studied section in Gavdos is connected with Messara basin located in the northeastern and, finally, that the main part of Gavdos basin, which is situated between Gavdos and Crete islands, has continuously encountered subsidence, we could conclude that sediments of Metochia Formation could act as source rocks but in the more deep central part of the Gavdos basin.
\end{abstract}

Key words: Neogene, Rock-eval pyrolysis, Organic matter.

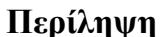

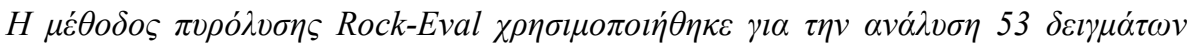

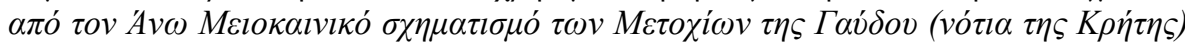

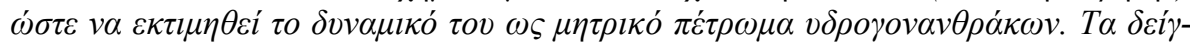

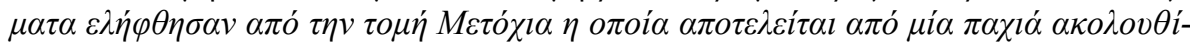

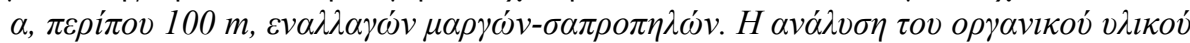

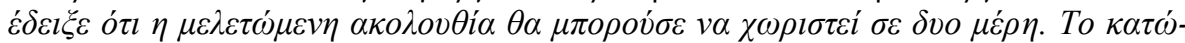

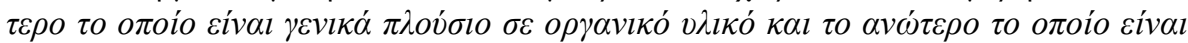

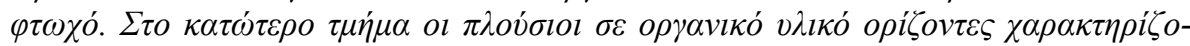

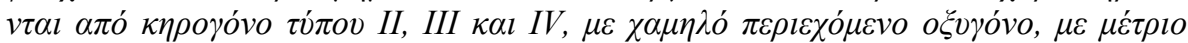

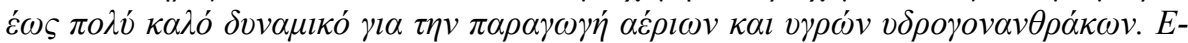




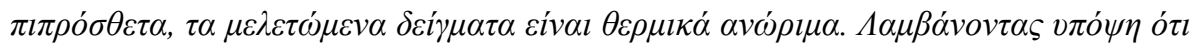

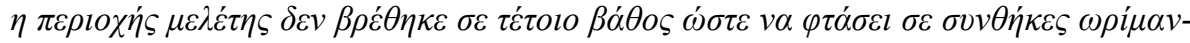

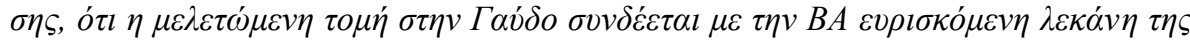

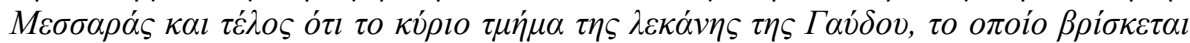

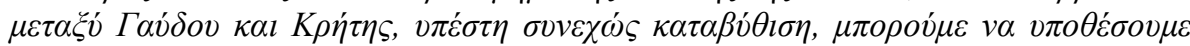

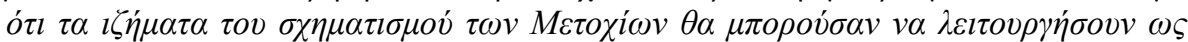

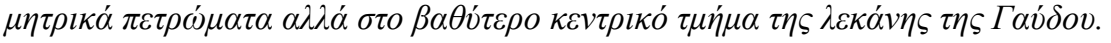

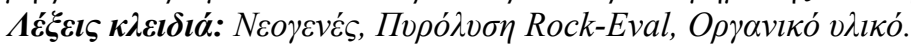

\section{Introduction}

This paper deals with the late Miocene sediments of Metochia Formation on Gavdos Island and their source rock potential. Metochia Formation consists of a thick sequence of marls-sapropels alternations. In general, sapropels are characterized by high ( $>2 \%)$ TOC (Total Organic Carbon) values. These high values of TOC make sapropels to be considered as possible source rocks for the generation of hydrocarbons. In case of Metochia Formation, TOC analysis of several sapropelic samples was carried out in order to examine the hydrocarbon generating potential. The fact that numerous biogenic gas seepages have been observed in the neighbouring Messara basin (Maravelis et al., In Press, Panagopoulos et al., 2011), which is located at North-Eastern of Gavdos, makes TOC-analysis campaign reasonable. More specifically, the observed seepages in Messara are connected with neogene deposits that belong to Tefelion Group (according to the classification of Meulenkamp et al. (1979)) and are time-equivalent with the neighbouring neogene deposits of Gavdos (van Hinsbergen and Meulenkamp, 2006, Zachariasse et al 2011). Additionally, the studied sediments are palaeogeographically located in the southernmost edge of Aegean landmass (Fortuin, 1978) and are dominated by Aegean terrigenous supply through a drainage system that covered the whole southern area of Aegean landmass, including Messara and Gavdos basins (Fortuin, 1978; van Hinsbergen and Meulenkamp, 2006; Köhler et al., 2010). Therefore it can be assumed that both basins constituted a single one for a specific period of time.

\section{Geological Settings}

Gavdos Island is located about $30 \mathrm{~km}$ southerly of Crete Island. Both Gavdos and Crete islands are between a volcanic arc in the North and a northward subduction zone in the South, which have been created from the subsidence of the African plate below the Aegean plate.

The preneogene alpine basement of Gavdos island consists of a Maastrichtian-Danian calcareous sequence topped by Eocene flysch (Vicente, 1970), belonging to the Pindos-Ethia geotectonic zone. Towards the northeastern part of the island, a Mesozoic volcano-sedimentary series is exposed (Vicente, 1970; Seidel and Okrusch, 1978), which according to Bonneu (1984) is thrusted above the Pindos-Ethia sequence.

The neogene sediments of Gavdos Island cover about one half of its surface. Anastasakis et al (1995) subdivided these neogene deposits into two distinct Formations based on lithostratigraphic and biostratigraphic criteria.

The older one is Potamos with a lower Tortonian age (Antonarakou et al, 2007). According to van Hinsbergen and Meulenkamp (2006). Potamos Formation recorded late Serravallian subsidence, containing coral limestone unconformably overlying the pre-Neogene basement, overlain by upper Serravallian mudrocks and sapropels (Anastasakis et al., 1995), deposited at around 500-600m water depth. The mudrocks and sapropels are overlain by shallow-marine sands, reflecting latest Serravallian to earliest Tortonian uplift. Zachariasse et al. (2011) suggested that Potamos Formation is time-equivalent with the fluvio-lacustrine sediments of the Viannos Formation and/or the marine Skinias Formation in central Crete. This suggestion was based on the correlation of age 
estimations that Zachariasse et al. (2011) conducted for neogene sediments of Crete with age estimations that Postma et al. (1993a) and Hilgen et al. (1995) conducted for Gavdos sediments.

According to van Hinsbergen et al (2006) (and reference therein) during late Serravallian (late Middle Miocene) an east-to west running longitudinal sedimentary system connects the river sediments of Males Formation in Ierapetra area with lacustrine sediments of Viannos Formation in central Crete and deep-marine sediments of Potamos Formation on Gavdos.

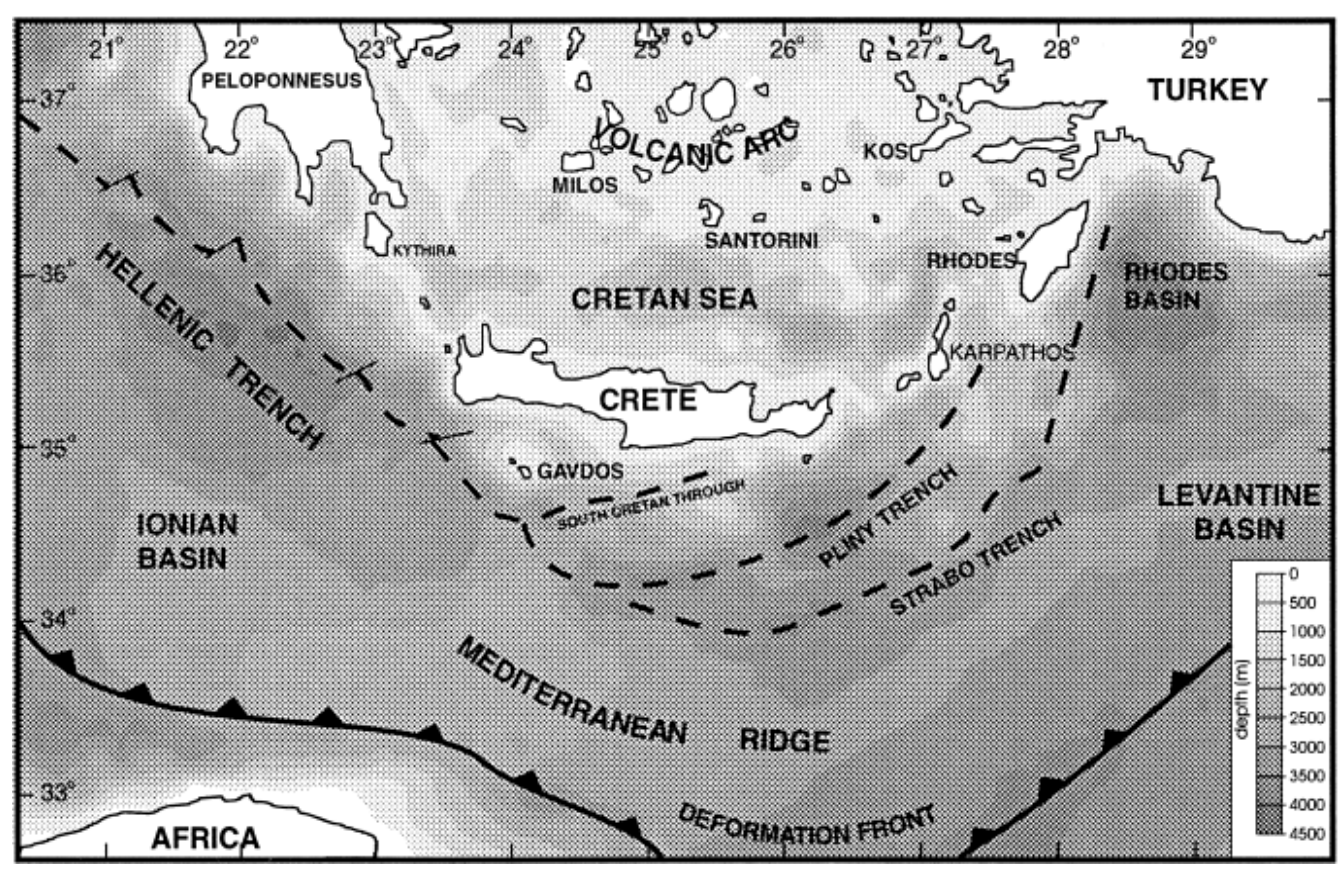

Figure 1 - Major structural features and bathymetry of the Aegean region (Duermeijer et al. 1998).

The second one is the Metochia Formation with a Tortonian-Messinian age (Postma et al., 1993a, Hilgen et al., 1995). Metochia Formation starts with a strong erosional surface over an intense angular unconformity forming on top of the alpine basement flysch beds or Potamos Formation (Anastasakis et al 1995, Drinia et al 2007). The most pronounced section of this Formation is the Metochia section, which is located in the North part of Gavdos Island. This section has a thickness more than $100 \mathrm{~m}$ and is one of the most well studied sections in the area of Eastern Mediterranean, covering a time-span from 9.8 to 6.6 million years ago. Metochia section is composed of two subsections (Metochia B and C), which are separated by a normal fault (Krijgsman et al. 1995, Stigter 1989). These subsections are correlated on the basis of characteristic lithology patterns (Krijgsman et al. 1995).

The basal part of the Metochia section starts with a paleosol horizon, followed by estuarine sediments and shallow marine sands rich in Heterostegina, echinoderma and molluscs. These sediments are overlaid by a marls-sapropels alternations sequence which are numbered L1 to L96 (Postma et al. 1993) (or M1 to M96 according to Hilgen et al., 1995, Krijgsman et al. 1995). In the lower part of the Formation the L1-L7 marls-sapropels alternations are gradually replaced of a turbidite sequence (L8-L11). A second interval of marls-sapropels alternations overlay the turbiditic sequence. According to van Hinsbergen and Meulenkamp (2006), Metochia Formation was deposited during an episode of pronounced subsidence, with deposition of the sediment at a water depth of more than $1000-1200 \mathrm{~m}$. Köhler et al. $(2008,2010)$ related a sharp decrease of the Aegean terrigenous supply being drained by fluvial systems into the Gavdos about 8,2 million years ago, with the change from paralic to marine sedimentation in central Crete at the same time. 
This section is conformably overlaid by a diatomitic sequence (about $15 \mathrm{~m}$ thick), which is covering the-time span between 6.6 and 6 million years ago (Drinia et al 2004, Gaudant et al 2005, Hilgen and Krijgsman 1999).

\section{Materials and Methods}

In the context of this study, sampling on Metochia B section was carried out. In Figure 2 there is the sedimentary log of Metochia B section and in Figure 3 there is a panaromic view of the sampling outcrop. Totally 53 samples were collected, among which 11 samples belong to the lower marls-sapropels alternations, 11 samples to the turbiditic sequence and 31 samples to the upper marls-sapropels alternations.

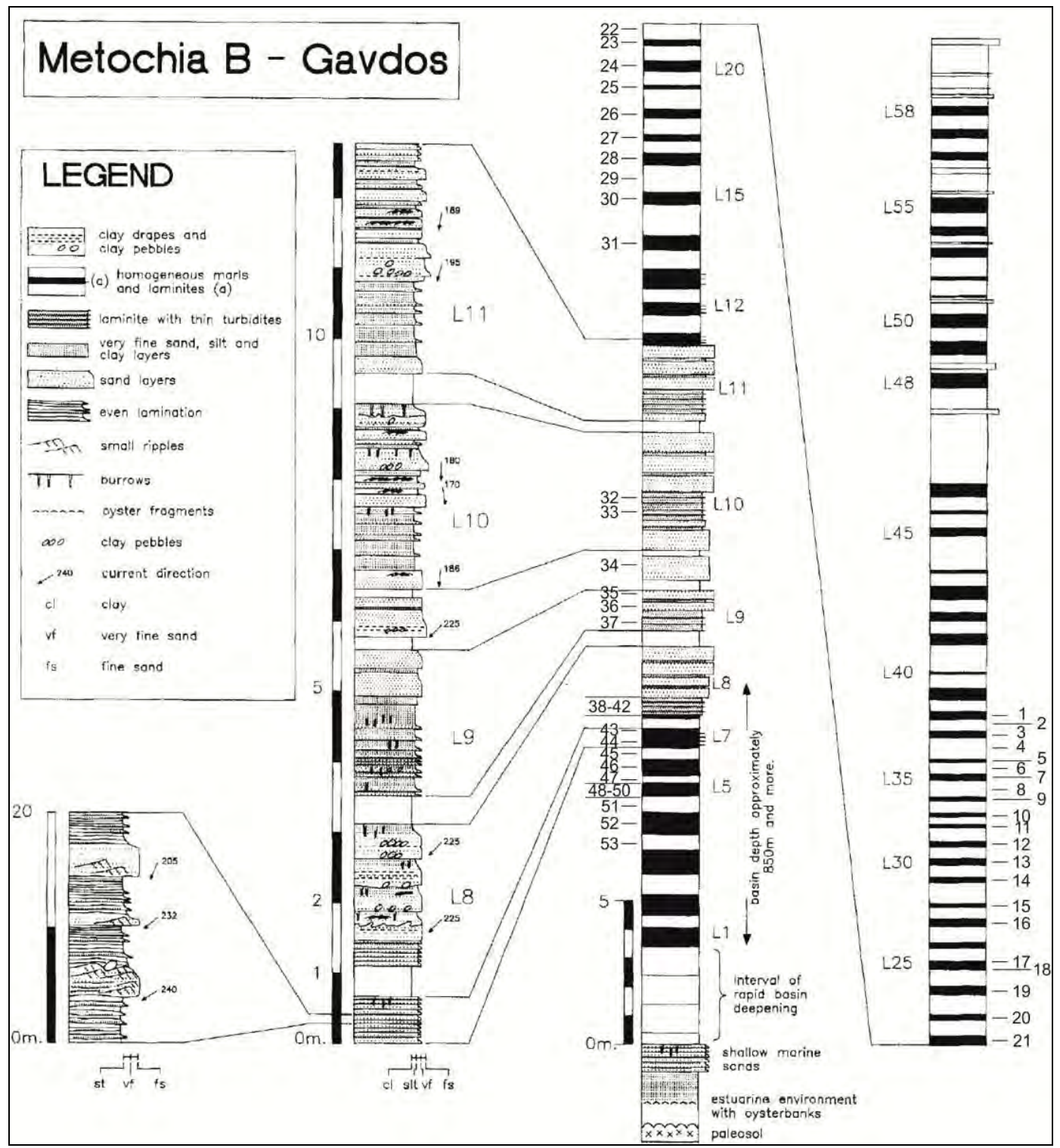

Figure 2. Sedimentary log of Metochia B section (Postma et al., 1993). Sampling horizons have been marked with numbers (1-53). 


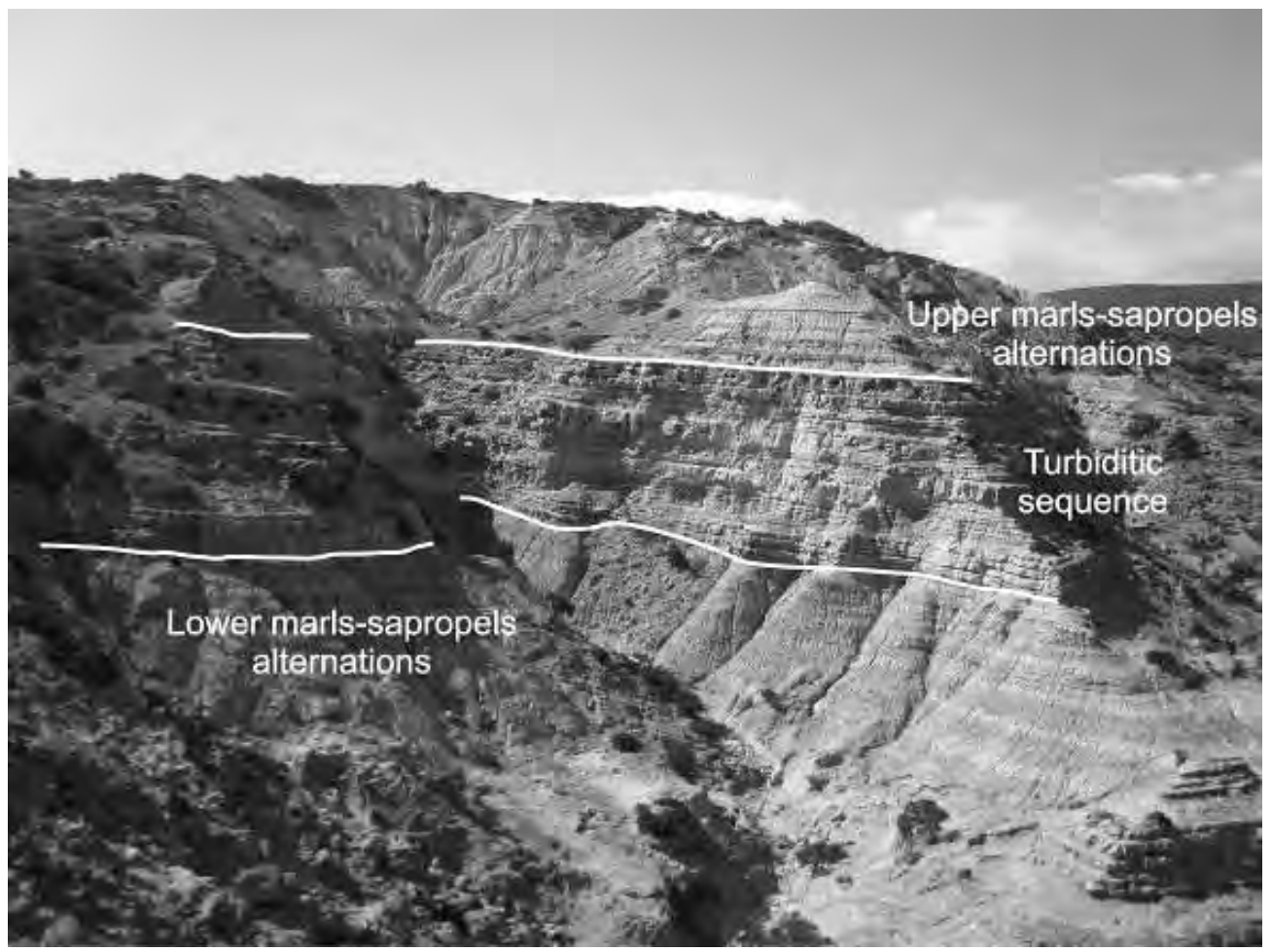

Figure 3. Panoramic view of the sampling outcrop (Metochia B section).

The samples, after being pulverized and dried at $100 \mathrm{oC}$, were analyzed in a Rock-Eval II (Delsi Inc.) analyzer following the typical experimental procedure of Espitalié et al. (1977). Each sample was heated in an inert $\mathrm{He}$ atmosphere for $2 \mathrm{~min}$ at $300 \mathrm{oC}$ and then pyrolyzed stepwise with increasing temperature at $600 \mathrm{oC}$ with a heating rate of $25 \mathrm{oC} / \mathrm{min}$.

The measured parameters of each pyrolysis run consist of three peaks (S1, S2, and S3) and a maximum temperature value (Tmax).

- S1: the area of the S1 peak characterizes the quantity of free hydrocarbons contained in the rock sample in $\mathrm{mg}$ hydrocarbons/g rock.

- S2: the area of the S2 peak characterizes the quantity of hydrocarbons produced by thermal conversion of kerogen contained in the rock sample in $\mathrm{mg}$ hydrocarbons/g rock.

- S3: the area of the S3 peak characterizes the quantity of organic $\mathrm{CO}_{2}$ produced during pyrolysis from the organic matter in the rock sample in $\mathrm{mg} \mathrm{CO}_{2} / \mathrm{g}$ rock. S3 index is an indication of the oxygen content in kerogen.

- Tmax: is the temperature which corresponds to the maximum generation of hydrocarbons from kerogen.

Additionally to these parameters during Rock-Eval pyrolysis, the total organic carbon (TOC) content of the sample is calculated from the S1, S2 and S4 peaks. The S4 peak corresponds to the $\mathrm{CO}_{2}$ generated from the oxidation in air at $600^{\circ} \mathrm{C}$ of the residual carbon (after pyrolysis).

Hydrogen (HI) and Oxygen (OI) indices were calculated, using the previous parameters.

- HI: is defined as $(100 \times \mathrm{S} 2) / \mathrm{TOC}$. The HI is proportional to the amount of hydrogen contained within the kerogen.

- OI: is defined as $(100 \times \mathrm{S} 3) / 100$. The OI is related to the amount of oxygen contained in the kerogen.

$\underline{\text { XLVII. No } 2-875}$ 

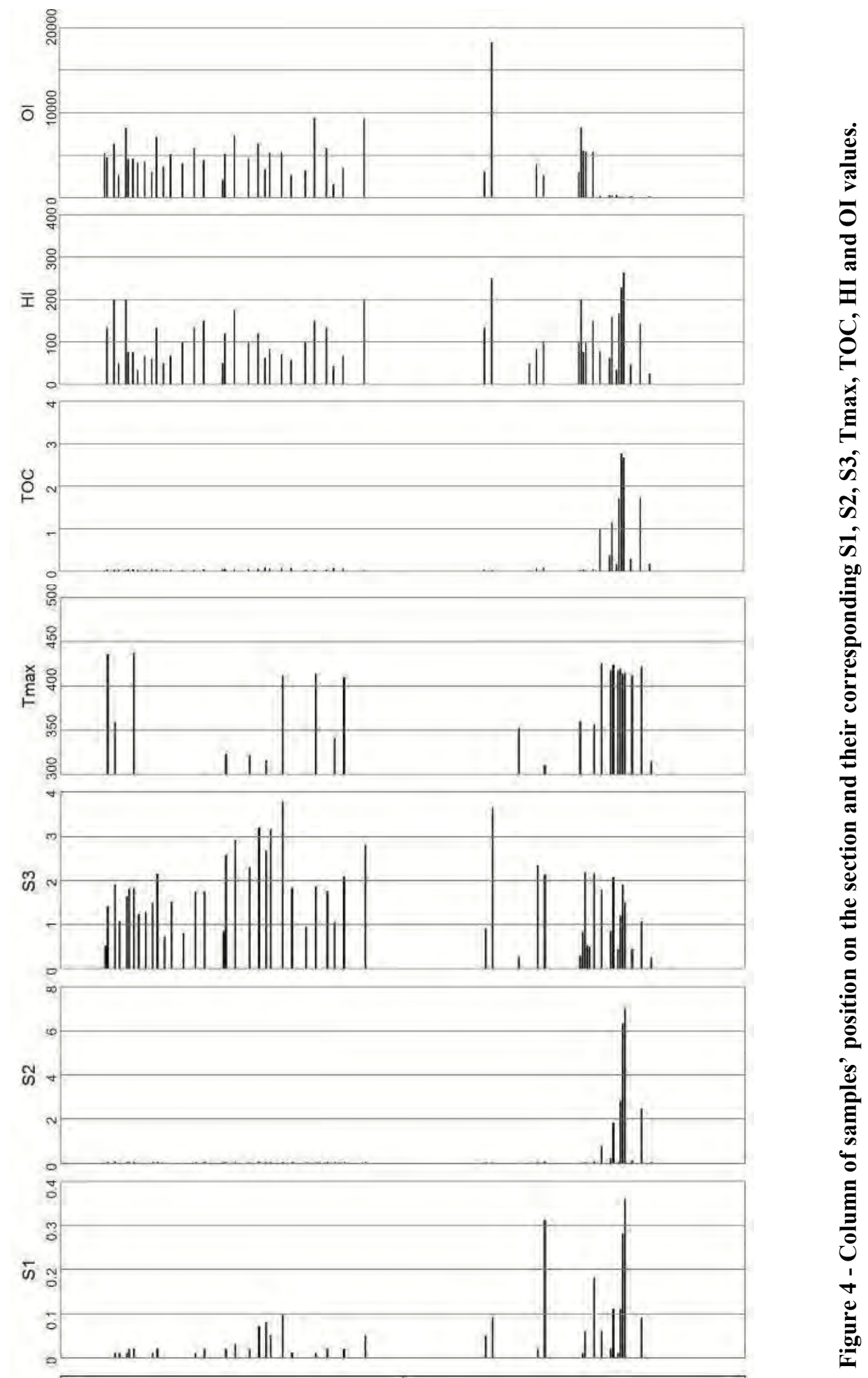

$\underline{\text { XLVII, No } 2-876}$ 


\section{Results}

The experimental results of Rock-Eval pyrolysis are graphically presented at Figures 4 with respect to the sample position in the section. The interpretation of the results, regarding source rock potential is based on the study of Espitalié et al. (1977).

The S1, S2 and TOC values are higher for the lower marls-sapropels alternations compared to the ones of the turbiditic sequence and the upper marls-sapropels alternations, where they practically equal zero. The values of S1 are lower than $0.5 \mathrm{mg} \mathrm{HC} / \mathrm{g}$, for all samples, showing poor source rock potential. S2 values show poor source rock potential for the samples belonging the turbiditic sequence and the upper marls-sapropels alternations. The values of this index for the lower marlssapropels alternations shows poor-to-good source rock potential. Similarly the interpretation of TOC values shows poor source rock potential for the majority of the samples, except of the samples from the lower marls-sapropels alternations, which show poor-to-very good source rock potential. S3 values are ranging between 0 and $3.78 \mathrm{mg} \mathrm{CO} 2 / \mathrm{g}$, for all the samples, indicating a kerogen with low oxygen content. In addition, Tmax values demonstrate immature organic matter.

The cross-plots of hydrogen (HI) and oxygen (OI) indices on the van Krevelen diagram as well as and HI vs Tmax diagram (Figures 5 and 6) demonstrate kerogen types III and IV. The HI vs TOC diagram (Figure 7), indicate poor oil potential but several samples show gas and oil generating potential. In these diagrams only samples from the lower marls-sapropels alternations, have been included, due to the extremely low values measured for the rest of the samples.

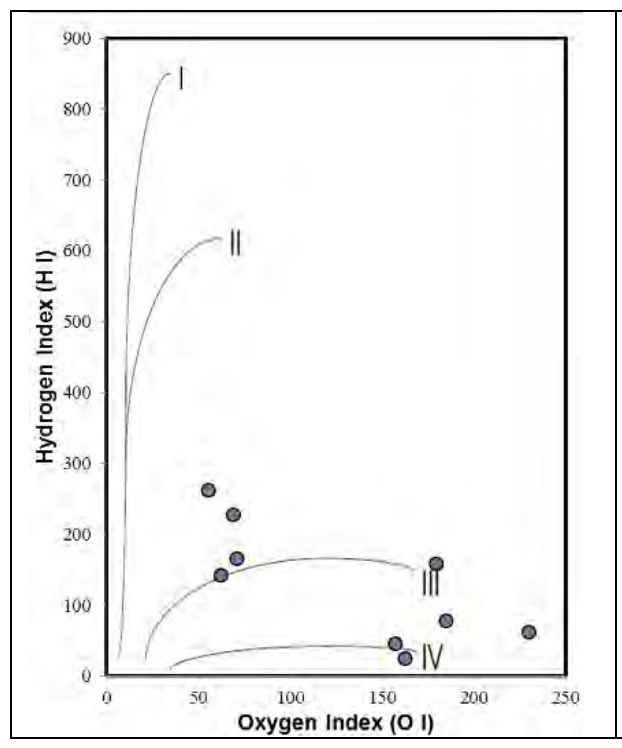

Figure 5 - Van Krevelen plot of the samples.

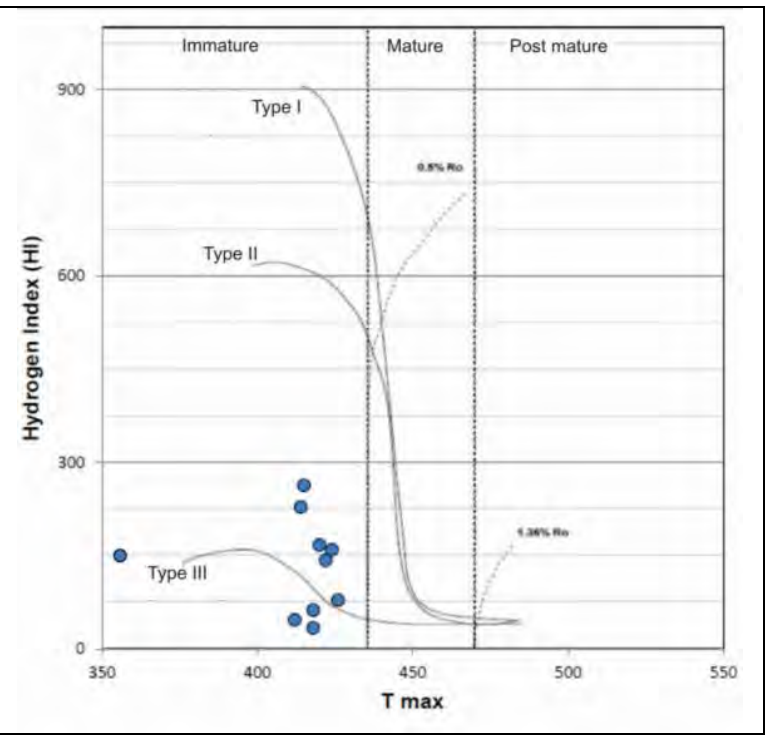

Figure 6 - Classification of the kerogen types by using Hydrogen Index vs. Tmax $\left({ }^{\circ} \mathrm{C}\right)$ diagram.

\section{Conclusions}

The Rock-Eval pyrolysis shows that the studied succession can be subdivided into two parts. The first one corresponds to the lower marls-sapropels alternations, showing poor to very good source rock potential for gas and/or oil generation, with thermally immature organic matter. The second part corresponds both to the turbiditic sequence and the upper marls-sapropels alternations, showing poor source rock potential. Despite the low thermal maturity of the samples from the first part of the section, it could be contented that their lateral equivalents can act as potential source rocks, considering that are buried in the northern and deeper parts of Gavdos basin where maturation conditions should be more favourable. 


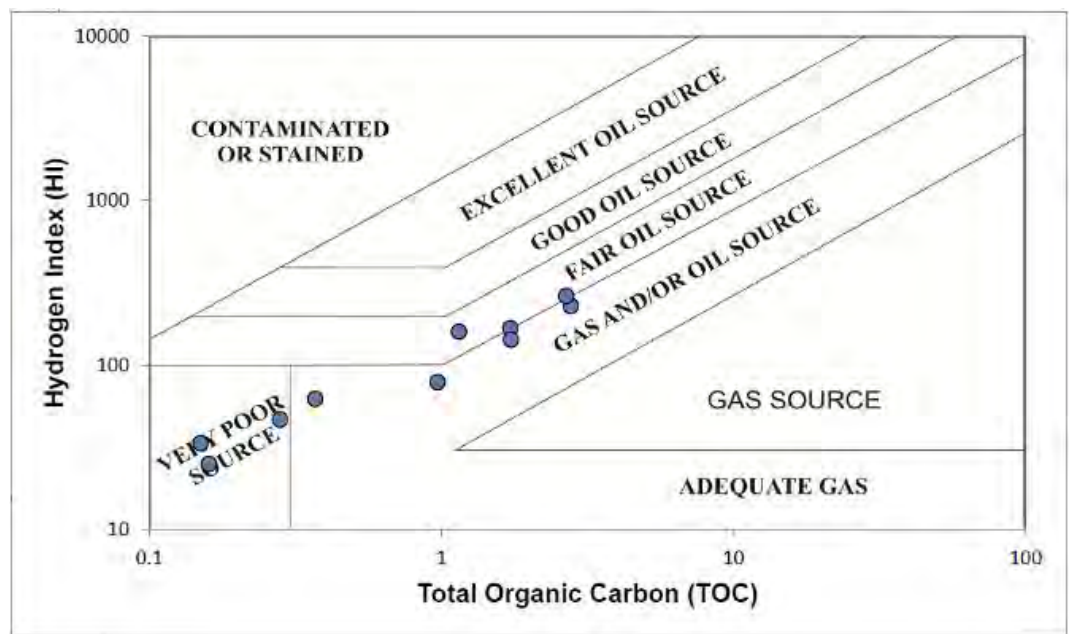

Figure 7. Hydrogen Index vs. Total Organic Carbon diagram of the samples (modified from Jackson et al., 1985).

\section{Acknowledgments}

This research has been co-financed by the European Union (European Social Fund - ESF) and Greek national funds through the Operational Program "Education and Lifelong Learning" of the National Strategic Reference Framework (NSRF) - Research Funding Program: THALIS -UOA"Messinian Salinity Crisis: the greatest Mediterranean environmental perturbation and its repercussions to the biota" (70/3/11605, MIS: 375405).

\section{References}

Anastasakis G.C., Dermitzakis M.D. and Triantaphyllou M.V. 1995. Stratigraphic framework of the Gavdos Island Neogene sediments: Newsl. Stratigr. v. 32, p. 1-15.

Antonarakou A., Drinia H., Tsaparas N. and Dermitzakis M. D. 2007. Micropaleontological parameters as proxies of late Miocene surface water properties and paleoclimate in Gavdos Island, eastern Mediterranean, Geodiversitas 29 (3): 379-399.

Bonneau M. 1984. Correllation of the Hellenic Nappes in the south-east Aegean and their tectonic reconstruction, in Dixon, J.E., and Robertson, A.H.F., eds., The geological evolution of the eastern Mediterranean, Volume 17: London, Geological Society of London, p. 517-527.

Drinia H., Antonarakou A., Tsaparas N., Dermitzakis M.D. and Kontakiotis G. 2004. Foraminiferal record of environmental changes: Preevaporitic diatomaceous sediments from Gavdos island, Southern Greece, Bulletin of the Geological Society of Greece vol. XXXVI. p. 782791.

Drinia H., Antonarakou A., Tsaparas N. and Kontakiotis G. 2007. Palaeoenvironmental conditions preceding the Messinian Salinity Crisis: A case study from Gavdos Island. Geobios 40, p. 251-265.

Duermeijer C.E., Krijgsman W., Langereis C.G. and ten Veen J.H. 1998, Post early Messinian counter-clockwise rotations on Crete: implications for the late Miocene to Recent kinematics of the southern Hellenic Arc: Tectonophysics, v. 298, p. 77-89.

Espitalie, J. Laport J. L., Madec M., Marquis F., Leplat P., Paulet J. and Boutefeu A., 1977. Methode rapide de characterization des roches meres de leur potential petrolier et de leur degree d' evolution, Revue de l'Institut Francais du Petrole, v. 1, XXXII, p. 23-42.

Gaudant J., Tsaparas N., Antonarakou A., Drinia H. and Dermitzakis M. D., 2005. The Tortonian fish fauna of Gavdos Island (Greece), Systematic Palaeontology, 4: 687-695. 
Hilgen F.J., Krijgsman W., Langereis C.G., Lurens L.J., Santarelli A. and Zachariasse J.W. 1995. Extending the astronomical (polarity) time scale into the Miocene, Earth Planet, Sci Lett., 136, 495-510.

Hilgen F.J. and Krijgsman W. 1999. Cyclostratigraphy and astrochronology of the Tripoli diatomite Formation (pre-evaporite Messinian, Sicily, Italy), Terra Nova 11, 16-22.

Jackson K.S., Hawkins P.J., Bennett A.J.R. 1985. Regional facies and geochemical evaluation of Southern Denison Trough, APEA J. 20, pp. 143-158.

Krijgsman W., Hilgen F.J., Langereis C.G., Lourens L.J., Santarelli A. and Zachariasse J.W., 1995. Late Miocene magnetostratigraphy, biostratigraphy and cyclostratigraphy from the Mediterranean. Earth and Planetary Science Letters, 136, 475-494.

Köhler C., Heslop D., Dekkers M.J., Krijgsman W., van Hinsbergen D.J.J. and von Dobeneck T., 2008. Fuzzy C-means cluster analysis on a late Miocene multiproxy data set of the eastern Mediterranean: constrains the disappearance of Crete as a sediment source, Geochem. Geophys. Geosyst., p. 9.

Köhler C., Krijgsman W., van Hinsbergen D.J.J., Heslop D. and Dupont-Nivet G. (2010) Concurrent tectonic and climatic changes recorded in upper Tortonian sediments from the Eastern Mediterranean, TerraNova, 22, 52-63.

Maravelis A., Panagopoulos G., Pyliotis I., Pasadakis N., Manutsoglou E. and Zelilidis A. (In press). Source-rock potential of the Late Miocene (Tortonian-Early Messinian) sediments of the Central Crete. Oil and Gas Science and Technology-France.

Meulenkamp J.E. 1979. Field guide to the Neogene of Crete, Publ. Dep. Geol. Pal. Univ. Athens, 32,32

Seidel E., and Okrusch M. 1978. Regional distribution of critical metamorphic minerals in Crete, in Closs H., Roeder D., and Schmidt K.E., eds., Alps, Apennines, Hellenides: 448-452, Schweizerbart, Stuttgart.

Stigter H. 1989. Neogene-Recent compressional tectonics in the southern Hellenic Arc, 34 pp., Intern. Rep. Utrecht Uni.

Postma G., Fortuin A.R. and Van Wamel W.A. 1993a. Basin-fill patterns controlled by tectonics and climate: the Neogene 'fore-arc' basins of Eastern Crete as a case history, In: Tectonic Controls and Signatures in Sedimentary Successions (Ed. by L.E. Frotick \& R.J. Steel), pp. 335-362, International Association of Sedimentologists, Special Publications.

Postma G., Hilgen F.J. and Zachariasse W.J. 1993b. Precession-punctuated growth of a late Miocene submarine-fan lobe on Gavdos (Greece), Terra Nova, 5, 438-444.

Panagopoulos G., Pyliotis I., Zelilidis A., Spyridonos E., Hamdan H., Vafidis A., Manoutsoglou E., 2011. 3D modeling of biogenic gas-bearing Neogene deposits at Arkalochori region, Messara, Crete, Greece, Proceedings of IAMG, Saltzburg 431-440.

Van Hinsbergen D. and Meulenkamp J., 2006. Neogene supradetachment basin development on Crete (Greece) during exhumation of the South Aegean core complex, Basin Research, 18, 103-124.

Vicente J.C. 1970. Etude géologique de île de Gavdos (Grèce), la plus méridionale de l'Europe. Bull. Soc. Géol. de France, 7(12) : 481-495.

Zachariasse W.J., van Hinsbergen D.J.J. and Fortuin A.R., 2011. Formation and fragmentation of a late Miocene supradetachment basin in central Crete: implications for exhumation mechanisms of high-pressure rocks in the Aegean forearc, Basin Research, 23, 6, 678-701. 